\title{
REDRESSING THE GROWING CONCERN OF THE EDUCATION SECTOR IN NIGERIA
}

\author{
KAZEEM, Kolawole PhD \\ and \\ IGE, Olusola \\ Faculty of Education \\ University of Benin \\ Benin-City, Nigeria \\ email: kayoomkazeem@yahoo.com
}

\begin{abstract}
The status of the Nigerian educational system at the moment is unenviable. It is low in quality and standard, limited in its reach and disturbing in its future. There have been some deliberate attempt/efforts by government to redress the declining fortune of the educational system. Some International donor agencies, like UNICEF, the World Bank, UNESCO, and DFID are also collaborating with government at all levels with a view to coming up with a holistic approach in addressing educational concerns. The intention of this paper is to enhance debates on how to redress past mistakes and unintended failures within the Nigerian education policies, programmes and provisions. The paper is of the view that Nigeria requires a system that will insulate education from unnecessary politicization. Education formulation and policy consideration should be for the good of all. The paper is also of the view that there is need for a holistic reorientation, re-engineering and re-branding of education, especially teacher training and recruitments, if effective quality of education is to be achieved in Nigeria. Government should also ensure that all reports, pronouncements and positions canvassed by educational accreditation, visitations and probe panels are implemented.
\end{abstract}

Key Words: Education, Minimum academic standard; Politicization of education; Quality, Teacher recruitment.

\section{Introduction}

Education in Nigeria is nationally conceptualized not simply as the medium for cultural transmission but the main vehicle for accelerating individual, community and national development. It is a mechanism through which the society generates the knowledge and skills required for its survival and sustenance. It enriches people's understanding of 
themselves and the world. It improves the quality of their lives and leads to broad social benefits to individuals and society.

The fortune of the educational system in Nigeria is, perhaps, at its lowest ebb. There has been a consistent denigration of the system in the last two or three decades. Graduates of the educational system are not only derided, but are also described as lacking in quality, low in perception and unfit in skills. Employers complain that school graduates are poorly prepared for work. In many cases, employers compensate for insufficient academic preparation by organizing remedial courses for new employees. Developed countries subject graduates of our schools to fresh training and examination in an attempt to ensure fitness into their own System. The educational foundations of our society are presently being eroded by a rising tide of mediocrity that threatens our future as a nation and a people. Findings from educational sector analysis confirm the poor state of education in Nigeria. The national literacy rate is currently 57 percent. Some 49 percent of the teaching force is unqualified. There are acute shortages of infrastructure and facilities at all levels. Access to basic education is inhibited by gender issues and socio-cultural beliefs and practices, among other factors. Wide disparities persist in educational standards and learning achievements. The system emphasizes theoretical knowledge at the expense of technical, vocational, and entrepreneurial education.

Concern about quality of education is uppermost in all educational discourse all over the world. Indeed, debate about the relevance and quality of education has been a recurring issue in education reform of all nations. This development is not lost on Nigeria. In the spate of its existence as a nation, Nigerian education system has been subjected to evaluations and reforms. A number of commissions, conferences and meetings have been put in place to examine the country's educational system (Gusau, 2008). Despite the efforts in developing the sector, Nigeria's education has '... had the problems of political changes, inadequate funding, hurried plans without accurate data, lack of proper monitoring and evaluation of the projects and programmes and lack of accountability' (Eya, 2000).

The intention of this paper is to enhance debates on how to redress past mistakes and unintended failures within the Nigerian education policies, programmes and provisions, bearing in mind that Nigeria has missed the Education For All (EFA) goal of achieving gender parity at the primary and secondary education levels by 2005 and is likely to miss achievement of other Millennium Development Goals (MDGs) by 2015. The paper will therefore attempt to review of some Post-1983 educational policy 
pronouncements, examine the education challenges, attempt to redress the trend, review effectiveness of the measures and suggest a way forward.

\section{Review of Policies Pronouncements after 1983}

Prior to 1984, the Nigerian education system could boast of a number of well thought-out policy directions envisioned in both the National Development Plans and the National policy on Education. Schools were less crowded; there were some measure of academic excellence, as schools witnessed little or no disruptions from strike and riots; entrance into institutions of higher learning were quite competitive; cultism, violent and brazen examination malpractices and indecent behaviour among students and teachers were not a virtue.

Beginning from 1984 however, a number of policy pronouncements were made that can be said to have major effect on education at all levels. For instance, the democratic government of Shagari inaugurated the Open University of Nigeria in 1982. The project was designed to address the problem of access to University education in Nigeria. But that policy was abrogated by the Buhari/Idiagbon regime in 1984. It is also on record that the Buhari administration cancelled the feeding programme and bursary for education students in institutions of higher learning. The administration also truncated the 10-year national mass literacy campaign put in place by the Shagari government in 1980. The reason behind these decisions was that revenue accruing to government had gone down considerably and government could not afford financing and prosecuting such programme.

The aftermath of the cancellation of the feeding programme in higher institutions is that students who hitherto needed $=\mathrm{N}=1.50 \mathrm{k}$ a day to feed were required to find alternative means of survival in school. Thus students had to resort to some unusual numerical terminologies, 100, 010,001 etc. These figures signify how many times per day one ate. If it is one time it could be 100 (breakfast), 010 (lunch), 001 (dinner) (Gusau, 2008). It also resulted in the total dislocation of indigent students, who constitute more than $90 \%$ of the student population. The outcome of this policy can be found in students especially females 'using what they have to get what they need'.

The Babangida administration (the longest military administration in Nigeria) may be credited with some major decisions that were to move education forward, but few of these policies did not totally advance the course of education. For instance, following the Structural Adjustment Programme (SAP) in 1986, higher institutions of learning were mandated to search for alternative sources of funding. The 
effect of that directive, to my mind, resulted in the introduction of all manners of programmes in institutions of higher learning. It equally led to the establishment and proliferation of satellite campuses all over the federation. While some may argue that the policy opened access to education, the truth is that the proliferation and introduction of all manners of parttime and diploma programmes have done more harm than good.

It must be said that the magnitude of the problem created by the policy has continued to live with University education and rubbed off on all the other levels of education especially Polytechnics and Colleges of Education. For instance, here was a system that has strict admission policy, suddenly becoming haven for all manners of funny entry qualifications and students. Diploma programmes which were designed for skill improvement of some categories of civil servants became the main admission requirement into direct entry programme. Sub-degree programmes were also organized more for the financial requirement of the institutions than the academic excellence the schools were to promote. Most institutions also started lowering admission requirements in an attempt to rake in more funds. The result of this development can be seen in students whose quality has gone down, and students buying their way through schools became the norm. Where they could not buy their ways, they resorted to violence in obtaining the score they want. This development made cult activities attractive in most institution of higher learning.

Primary and secondary education was designed to be administered by local and state governments respectively. Owing to the centralized nature of military administration in Nigeria however, the Federal government took charge of all education matters. The directive seeking to put the administration of primary education in the local government by the Babangida administration was a novel move. Unfortunately, the move was taken without giving those to execute it the right training and positive frame of mind to carry out the task. The result of the policy came out in unpaid salaries of teachers for months. This resulted in primary teachers going on strike for six month in 1993. The problem virtually led to the total collapse of that sector. Indeed, the sector has not recovered from the dislocation of that policy till today.

One can safely claim that education from 1984 promoted or threw up a number of challenges, but some of these policies have been corrected or reversed with the coming of democratic government in 1999. For instance, government after 1999 directed that all satellite campuses be closed and accreditation of degree programmes be streamlined. National Open University of Nigeria which was aborted by the Buhari administration was 
re-established and has continued to provide access to those who would have missed the opportunity of University education. The gate of establishing Private Universities has also been widely opened since 1999. Universal primary Education programme has come with an acceptable administrative structure. In spite of the post-1999 efforts at developing the sectors however, most of the problems still abound in almost all the areas of the sector.

\section{Education Challenges}

The status of the Nigerian educational system at the moment is unenviable. It is low in quality and standard, limited in its reach and disturbing in its future. Beneficiaries of the education system in the period before mid1970 claimed that this sorry state is something of very recent history. The contention is that the quality of education in Nigeria before this period compared favourably with any educational system in the world; but the state of education today is far from being ideal. Teachers' strikes at all levels of education and incessant closure of schools have become the norm. Cultism and violent crime are common in institutions of higher learning in most parts of the country. Examination malpractices and admission racketeering is a common phenomenon. Un-conducive teaching and learning environment abound everywhere, teacher quality and quantity, poor remuneration, dilapidated infrastructure, and inadequate learning and teaching materials at all levels of education are the lots of education in Nigeria.

One area of profound concern in education is the number and quality of teachers in schools at all levels. If the dictum 'no education can rise above the quality of its teacher' is true, then the calibre and quality of persons recruited into teaching and teacher education programmes may not be able to see the nation to the 'promised land' of education for all. It is my belief that the nation can only attain education excellence if the quality of its teacher is enhanced. As it is today, teacher education is unable to attract the best brains into the system. Students admitted to read education courses are not only of low quality, some are mostly reluctant students. The major reason adduced for this is perhaps the poor remuneration for teachers and the status of the teacher in the society. For instance education students are not considered as worthy of benefiting from the Industrial Attachment Fund (ITF) programme. Hence, most graduates of teacher education are incensed about the idea of taking up teaching as a profession. Consequently, more than $60 \%$ of teachers in the education sector are ill-equipped, ill-trained, ill-motivated and unqualified for the system. 
The problem of quality of teacher in the system can also be traced to teachers' recruitment practice. The practice is doing more harm than good to Nigerian education. Recruitment of academic staff into public education institution at all levels is no longer based on the time-honoured rigorous process. Departments and Faculties in most institutions no longer have a say in the recruitment of staff. Heads of Departments are now directed to "admit or appoint bearer'. The situation is worse in Colleges of Education and Polytechnics, where the Ministries direct Provosts and Rectors to 'admit bearer'.

Poor remuneration of teachers is another challenge facing education in Nigeria. To make ends meet, teachers' resort to 'self help projects'. While Primary and Secondary teachers became petty traders in their schools, academic teachers in tertiary institution became 'emergency book sellers', publishers and printers. Indeed, students who refuse to buy the books or handout produced by these teachers are guaranteed carry-over in such courses. Others demand 'money for grades'. High grades and scores are reserved for the highest bidders. Thus most teachers spend little time helping students to learn. Little wonder then that quality in moist institutions has been compromised.

Another profound challenge to education is the problem of incessant disruptions of academic programmes at all levels of education. At the heart of these disruptions is the issue of funding of education. Academic staffs at all level declare strike for improved funding, better and improved working condition and upgrading of teaching and learning facilities. Students' riots, on the other hand, are reaction to increase in school fees or hostel accommodation. These disruptions lead to school closure for weeks or months. Most times students are denied opportunity to make up for lost times. This results in low quality of student academic accomplishments.

Cultism in school is another problem. It is now a phenomenon in virtually all levels of education. The cause of this can be traced to a number of factors. First, the issue of institutions looking for additional sources of funding resulted in the introduction of all manners of part-time and. diploma programmes in higher institutions. Such programmes became homes for those who are ill-equipped for higher education. Secondly, the replacement of Advanced Level (A/L) certificate with diploma certificate as admission qualification into the University, coupled with increased falsification and certificate racketing at the school certificate level also brought about the admission of people who did not have what it takes to undergo the rigour of University education (Kazeem, 2004). Thus, cult groups became an attraction to such students. It has been 
observed that majority of students in cults are those who gained admission with arrangee (fake) school certificates or products of the diploma programmes. They also constitute majority of those involved in one form of examination malpractice or the other.

\section{Attempts to redress the trend}

There have been some deliberate attempts/efforts by government to redress the declining fortune of the educational system. The Federal government has at various times established institutions to formulate and ensure the quality of education at all levels. In 1985 for instance, the Federal government promulgated decree No 16 on minimum standards for primary and secondary education nationwide. The National Board of Technical Education (NBTE) and National Universities Commission (NUC) were established to cater for Polytechnics and Universities respectively. There is also the establishment, in 1989, of the National Commission for Colleges of Education by an act as the third leg of the tripod in the supervision of tertiary education in Nigeria. These institutions have the mandate to set Minimum Academic Standard (MAS) for the institutions listed in their respective schedules. For instance, the NUC sets the MAS for all Universities. The document prescribes specifications on: floor space for lectures and laboratory facilities per student ratio for effective teaching and learning in any given discipline; the curriculum and entry/graduation requirement for each discipline are also provided (NUC, 1999). The management of Primary and Junior secondary education was given a boost with the establishment of the Universal Basic Education Commission in 2001.

The Federal Ministry of Education in collaboration with some International donor agencies, like UNICEF, the World Bank, UNESCO, DFID are collaborating with government at all levels with a view to coming up with a holistic approach in addressing educational concerns. UNICEF for instance, is promoting the education sector strategic and operational plan. The measure is to take care of identified concerns of Primary, Secondary and Non-formal education.

Attempts at curbing major decadence among students especially in higher institutions have been mounted in most schools. Some institutions and faculties have started enforcing dress codes for students. Examination malpractice issues at both institutional and public examinations are being addressed. Aside from various sanctions given to culprits in schools, major examination bodies have devised various means of minimizing the menace. Some institutions have out rightly stopped diploma programmes, while others have streamlined or reduced the number of diploma and part- 
time programmes, in a bid to reduce incidences of cultism and violent crimes in their institutions. It should be added that the adoption of the Post -UME: screening exercise in most Universities, which is expected to improve student quality, is capable of redressing and reducing the incidences of examination malpractices, cultism and violent crimes in tertiary institutions on the long run.

Teacher quality is expected to be addressed with the introduction of the Teachers' Registration Council (TRC). Various institutions are adopting various measures to address indecent behaviour among teachers. For instance most Universities, with perhaps the exception of some State Universities, are enforcing the ban on sales of handouts, and unstandardized books. All these measures are efforts aimed at setting and improving education standards, thereby building the confidence of stakeholders in the quality of the education system.

\section{Effectiveness of the measures}

There is no denying the fact that most of the commissions and institutions charged with standard and quality control of education in recent times have been doing a yeoman's job. The UBEC for instance has been living up to expectation in monitoring the activities of State Education Board and the performance of the Universal Basic education Programme. The effectiveness of UBEC can be seen in prompt payment of teachers' salaries and other benefits. The NUC since 1999 has conducted several programme accreditations and visitations to all the Universities. The Universities today are more responsive to NUC than ever before.

With regards to cultism, admission racketeering, certificate forgery and examination malpractice; one can safely say that the steps put in place have the potency of redressing these decadence. For instance the introduction of Post-UME screening has effectively put paid to issues of admission racketing and reduced incidences of examination malpractice and cultism. Certificate screening has helped a great deal in reducing the problem of certificate forgery. There is evidence to show that products of Post-UME have shown and demonstrated remarkable commitment to their studies than pre-Post-UME students.

It should be observed however, that while the Universities are taking these measures, other institutions of higher learning seem to be lagging behind. Little or no progress is being made in these institutions to adopt some of the measures described above. For instance, Colleges of Education and Polytechnics still rely on JAMB examination for placement of students. This perhaps may be responsible for continued report of cultism and violent crimes in these institutions. There may be need for the 
Polytechnic for instance to introduce their equivalent of Post-UME or a form of screening examination for those seeking admission into the Higher National Diploma (HND) programmes. This will not only help in removing violent prone candidates, but it will also help in enhancing the quality of students admitted for HND. To me JAMB should commence examination for applicants into the HND programme and discontinue with admission examination into the Ordinary National Diploma (OND) programme, as there seems to be no pressure on admission into the programme.

As for Colleges of education, there is the need for government to realize that the business of education should not be put in the hand of second class materials. The practice of arranging crash-programme whenever a new education policy is put in place is unfortunate. It is dangerous to see the business of teaching as a vocation for just anybody. Teaching is a specialized profession. It has its principles and practice, as such it should not be left in the hands of those lacking in its skills. We therefore need to redefine the qualification of those to be enrolled for teacher education at all levels. The recent pronouncement by the NUC that the minimum qualification for lecturing in the University is a $\mathrm{PhD}$ is a welcome development. One should remark that in addition to this, government and the various commissions and institutions should enforce the policy which demands that teachers at all levels of education should obtain at least a diploma in education before being be recruited.

With regards to teacher quality, government has developed measures for upholding minimum teacher quality, especially at the Primary and Secondary levels. This much cannot be said of higher institutions. However, the University of Benin has adopted a practice wherein students are given opportunity to assess their teachers. The outcome of the exercise is being proposed as part of promotion criteria.

\section{Where do we go from here?}

At the inception of the present democratic government in 1999, the Nigeria educational sector was performing at a relatively low efficiency level. The story today is a little different. As observed earlier, government at all levels have introduced measures aimed at redressing some of these challenges. Some are short term while others are long term in nature.

It should be remarked however, that the Nigerian education sector has never suffered from having the best of philosophy and policies, what has been the problem is policy inconsistency. Whenever a new government comes into office, it has the tendency of discontinuing the policy of its 
predecessor in office. For instance, the Obasanjo presidency introduced the privatization of unity schools towards the end of its tenure in 2007, only for the Yar'Adua administration to reverse the policy without actually looking at the rationale for the policy.

What Nigeria requires at the moment is for government to divorce education from unnecessary politicization. The politics of education demands that the good of the people should override political, sectional or individual considerations. Education formulation and consideration should be for the good of all. There is therefore the need for a holistic reorientation, re-engineering and rebranding of education along the few suggested remedies, particularly as it relates to teacher training and recruitments into the educational sector. Government should also ensure that all reports, pronouncements and positions canvassed by educational accreditation, visitations and probe panels are implemented. As at the moment, most reports are not worth the paper on which they are written.

\section{References:}

Ajayi, I. A. \& Ekundayo, H. T., (2008): "The Deregulation of University Education in Nigeria: Implications for Quality Assurance", Nebula 54, pp. 212-224, December

Federal Ministry of Education (2000): Implementation Guidelines for the UBE Programme, Abuja, Federal Ministry of Education, February.

Federal Ministry of Education (2002); Guidelines on Minimum Standard for Schools Nationwide: submission for JCCE sub-Committee.

Gusau, B. U., (2008): "Educational Reforms in Nigeria: Successive Years of Inconsistencies and Confusions", Paper presented at Gusau educational development association (GEDA), interactive session. January

Imogie, A. I. (1999): Do you know who is teaching Your Child? Benin City, Inaugural Lecture Series 53.

Kazeem, K. (2004); "Redressing Cultism in H gher Institution", Paper Presented at the UNIBEN 4R Programme, at UNIBEN Central Mosque.

National Universities Commission (1999): Manual of Accreditation procedures for Academic Programmes in Nigerian Universities, Abuja, NUC.

Omolewa, M. (2001); The Challenges of Education in Nigeria, Ibadan, Ibadan. i University Press.

Teachers' registration Council (2002): benefit of being a registered Professional Teacher 